\title{
The King is Dead, Long Live the King! Jewish Funerary Performances in the Iraqi Public Space
}

\author{
A. Schlaepfer*
}

\section{Introduction}

This article engages in an analysis of the two royal funerals that took place in 2oth Iraq - that of King Fayṣal (1933) and King Ghāzì (1939) — and JewishMuslim interactions in the Iraqi urban space. The processions organized after their death by their subjects "of every creed" were numerous. Muslims, Jews and Christians alike repeatedly proceeded in the streets of Iraqi cities covered in black, beating their breast (men), moaning loudly (women) and covering their faces and chest with mud. Extensively commented on by officials and witnesses, these events offer a unique glance at the way Iraq's numerous communities invested the public space and at how they interacted in it. For non-Muslim citizens such as the Jews, these occasions represented an opportunity to assert their desire to coexist with other communities, their struggle against sectarianism (țāifiyya), loyalty to the State, the king and the Iraqi Arab nation. By studying these ceremonies as performances - whereby participants show others what they are doing in order to influence their judgment-the paper aims at shedding light on the function of these ceremonies and the role played by Jews in the Iraqi public space. Fayșal being more popular among Iraqi Jews than his son Ghāzī, one could expect the ceremonies organized by Jews in the memory of Fayșal, to be more expressive of their grief than those organized in the memory of Ghāzī, but the following analysis will prove otherwise. Based on testimonies from internal and external actors alike (accounts by Iraqi Jewish witnesses, journalists, correspondence between teachers at the Alliance israélite universelle and the headquarter in Paris, British and American officials), the article intends to demonstrate that the Jews' public expression of grief was not proportionate to the degree of sympathy they actually

\footnotetext{
* I am very grateful to Daniel Barbu, Aomar Boum, Eva Nada and the editors of the present volume for their thorough reading of this article and their invaluable comments.
} 
felt for their monarchs. By comparing the behavior of Iraqi Jewish participants to the ceremonies - such as street processions, public speeches, chants, physical and oral expressions of grief, as well as the media coverage-organized after Fayșal's death and those that took place after Ghāzīs death, it will show that the performances of the Jewish mourners responded to the necessities of the socio-political context at the time of the kings' death, rather than that of grief.

\section{The Jewish Funerary Ritual as a Performance}

According to Durkheim, the grief expressed during a particular ritual is eminently social and independent of the individual's affective state. The grief is a collective assertion that the individual consents to be part of rather than a spontaneous or personal expression of sadness. ${ }^{1}$ Participants in a ritual thus deliberately play a role and act in a similar fashion as they would in a theatre play: Contrary to everyday life, they show spectators what they are doing in order to influence their judgement. Pursuing the analogy with acting, Turner defines the ritual as a performance, during which messages are communicated. ${ }^{2}$ But the distinction between actors and spectators is less clear in a funeral: participants act and watch at the same time during a funerary ceremony, while it is not the case in a theatre play. In this sense, the funeral is closer to Bakhtin's reading of the medieval carnivalesque. Throughout the carnival, he argues, the participant who is both actor and spectator parodies and imitates real life with costumes, chants and dances. The process is similar with funerals: Mourners play a role as both actors and spectators in the ceremonies. Their motion, text and clothing are not pure fiction, they imitate real life in a caricature fashion. And by playing real life in a caricature, the carnival-like the funeraltemporarily suspends social order, and thus symbolically forces out boundaries of the everyday life. Rules are consequently overthrown, hierarchies reversed, and the structure turned over. ${ }^{3}$ This liminal phase is a moment during which a breach is momentarily made possible between all social, ethnic or religious boundaries. ${ }^{4}$ Participants reach a state of communion that transcends all these

1 Emile Durkheim, The Elementary Forms of the Religious Life, trans. (London: Courier Dover Publications, 2012), 397-400.

2 Victor Turner, The Anthropology of Performance, (New York: PAJ Publications, 1988), 72-98.

3 Mikhail Mikhălovich Bakhtin, Rabelais and His World, (Bloomington: Indiana University Press, 1984), 7 .

4 For the rites of passage and liminality, see Arnold van Gennep, Les rites de passage: étude 
ordinary barriers and together they unite. Turner names this slippery moment of epiphany communitas or anti-structure. ${ }^{5}$ For an Iraqi such as the Jews, the temporary absence of structure characteristic of the communitas represented an ideal opportunity for them to send an explicit message to others, as they could be as visible and as vocal as the other communities could be. Citizens are equal in mourning, one could say.

\section{The Funerary Ritual: Between Predictability and Malleability}

In a Hobsbawmian reading of modern history, the repetitive nature of traditions is important, especially in a period of crisis when stability needs to be constantly reaffirmed, through established and regular public practices. Repeated traditions imply continuity with the past and thus give the impression that they remain unaltered over time. ${ }^{6}$ The Middle East in the post-Ottoman era in particular was a period of great changes. The sharif Husayn of Mekka (Fayșal's father) had long aspired to obtain an Arab Kingdom or Caliphate, but had instead inherited the small Kingdom of Hejaz, and lost it almost immediately. His son 'Abdallah was appointed King of Jordan, while Fayșal became King of Iraq, after a first and unsuccessful coronation in Syria. Needless to say, the Hashemite monarchies were desperately seeking homogeneity, stability and strength, precisely because the context indicated otherwise. Such traditions as royal funerals were therefore crucial for the monarchy to reassert its power, stability and control over its subjects.

Despite these efforts, however, many aspects obviously varied in practice, from one funeral to another. For instance, the sharif Husayn of Mekka died in 1931 in Amman, and Fayṣal died in 1933 in Switzerland. Originally, both

systématique des rites, (Paris: E. Nourry, 1909); Victor Turner, The Ritual Process: Structure and Anti-Structure, (London: Routledge and Kegan Paul, 1969).

5 Victor Turner, The Ritual Process, 94-97.

6 Traditions are a "set of practices, [...] of a ritual or symbolic nature, which seek to inculcate certain values [...] by repetition, which automatically implies continuity with the past." Eric Hobsbawm and Terence Ranger, eds., The Invention of Tradition, (Cambridge: Cambridge University Press, 1983), 1. See also the article in the same volume by David Cannadine, "The Context, Performance and Meaning of Ritual: The British Monarchy and the 'Invention of Tradition', c. 1820-1977", in Eric Hobsbawm and Terence Ranger, The Invention of Tradition, 105: "[...] in a period of change, conflict or crisis, it might be deliberately unaltered so as to give an impression of continuity, community and comfort, despite overwhelming contextual evidence to the contrary." 
their bodies were supposed to be taken to Jerusalem at some point. In the case of Husayn, the body did arrive in Jerusalem by car where the procession met representatives of the Chief Rabbinate and of the Jewish Agency, as well as of various Muslim and Christian societies, at the Old City's Herod's Gate. The coffin was then carried into the Dome of the Rock and to the Mosque of Al-Aqsa, and the burial eventually took place next to the Haram area. A small window was opened in the wall of the holy place in order to connect it symbolically to Husayn's tomb. The British High Commissioner for Palestine asserted that "no untoward incident of any kind occurred during the funeral".7 However, in the case of Fayșal's body, a religious ceremony was also originally supposed to take place in Jerusalem on its way from Haifa to Baghdad, but the coffin was "taken direct to Baghdad by air", 8 in order to avoid potential political excitement, according to British officials, ${ }^{9}$ because at the time of Faysal's death, interreligious tensions were much higher.

The difference shows how the socio-political context influences the way the ceremony is held. "Men resemble their time more than they do their fathers", ${ }^{10}$ states the French historian Marc Bloch, quoting an Arab proverb. In other words, the funeral not only serves the purpose of a ritual as a preestablished and predictable set of movements, but also acts as a malleable, "elastic and dynamic"11 product, in which a mosaic of elements interact and converge. ${ }^{12}$ Parts of a funeral therefore follow the rule of predictability, while other parts vary according to a changing context and therefore follow the rule of malleability. Both similarities and dissimilarities signal a message; The former express the need for hegemony, while the latter-the focus of the present article - unveil the surrounding socio-political context.

$7 \quad$ "High Commissioner for Palestine, Jerusalem to colonial Office, 11 June 1931," in Records of the Hashimite Dynasties, A Twentieth Century Documentary History, ed. Alan de L. Rush, Vol. 4, (Slough: Archive Editions, 1995), 428-431.

8 "Paraphrase telegram from High Commissioner for Palestine to Colonial Secretary, London, 11 September 1933," in Records of the Hashimite Dynasties, ed. Alan de L. Rush, Vol. 11, 777 .

9 "Telegram from Foreign Office, London to Mr Murray, Rome, 9 September 1933," in Records of the Hashimite Dynasties, ed. Alan de L. Rush, Vol. 11, 776.

10 Marc Bloch, The Historian's Craft, trans. (New York: Knopf, 2004), 27-29.

11 David Cannadine, "The Context, Performance and Meaning of Ritual: The British Monarchy and the 'Invention of Tradition', c. 1820-1977", 106.

12 Julia Kristeva, Sēmeiōtikē: recherches pour une sémanalyse, (Paris: Seuil, 1978), 146. 


\section{The Jews and Their Monarchs}

In August 1921, Fayșal b. Husayn, son of the Hashemite dynasty of the sharifs of Mekka, was enthroned King of Iraq. Twelve years later, in September 1933, he died of a heart attack in Interlaken (Switzerland). He was succeeded by his son Ghāzī, aged 21, who ruled over Iraq for six years, before he was killed in a car crash in April 1939. His son Fayșal II succeeded him under the Regency of his uncle 'Abd Al-Ilāh, until he became of age (he was then three years old). During the July 1958 Revolution, the monarchy was overthrown by the General 'Abd AlKarīm Qāsim, and all members of the royal family were killed, thus putting an end to the Hashemite monarchy in Iraq.

In the collective memory of Iraqi Jews, Fayșal is most commonly remembered as a good sovereign, to which all sorts of benefits are attributed, such as promoting religious tolerance. In a speech he delivered a few weeks before his coronation during an official visit to the Jewish community in July 1921 he declared: "There is no such thing as a Jew, a Muslim, or a Christian. There is simply one thing called Iraq."13 Accordingly, Fayṣal's death is seen as a turning point, after which the "golden age" came to an end. Ibrāhīm Al-Kabīr, ${ }^{14}$ the Jewish accountant General of the Ministry of Finance, writes:

Faisal was succeeded by Crown Prince Ghasi who was proclaimed King of Iraq immediately after the death of his father. King Faisal was a genius with a great intellect, tremendous memory and deep and long sighted political acumen. His death created a vacuum which could never be filled and historians will record it as a turning point in the destinies of the Arab world and perhaps beyond it. ${ }^{15}$

Inversely, Ghāzī, known to be close to ultra-nationalistic circles and unsympathetic to the Jews, aroused fear and suspicion. Al-Kabïr continues:

13 Philip Willard Ireland, Iraq: A study in Political Development, (London: J. Cape, 1937), 466.

14 Ibrāhīm Al-Kabīr (1885-1973) was born in Baghdad in 1885. After the Iraqi State was created, he was hired by the minister of Finance Sāsūn Ḥasqayl, and became Chief Accountant in 1926. He was known as Abū al-'umla "father of currency" by his colleagues, because he was in charge of introducing an independent currency in Iraq. He is the author of an unpublished autobiographical pentalogy (1963-1970).

15 Ibrahim Al-Kabir, My Governmental Life, or Story of a Dream, 1964 (unpublished manuscript), 86-87. 
Ghasi was a man of mediocre intelligence, immature judgement and foresight. He was weak, irresolute and soon fell under the influence of young army officers. He was very friendly with me and in conversation he called me "My brother Ibrahim". I felt, however, I could not rely on the moral and material support I got from King Faisal in my dealing with unscrupulous ministers. My apprehensions were not unjustified and I expected that the shaky foundation of the State would soon be undermined. ${ }^{16}$

Similarly, Ișhāq Bar Moshe, ${ }^{17}$ a young Baghdadi Jew, recalls memories from his childhood in an autobiographical trilogy. He reports a conversation he heard between two adults right after Fayṣal's death in Bayt Fī Baghdād:

- Fayșal loved the Jews and protected them.

- And nobody knows how it will be after him, with Ghāzī.

- They say he is the opposite of his father; that he tends not to like the Jews.

- Fayșal knew the Jewish community notables and used to receive them.

- He is from the old generation; he did not have prejudices or passionate hostility towards the Jews. ${ }^{18}$

Robert Méfano, deputy director of the Alliance israélite universelle (AIU) school in Baghdad, describes the backroom atmosphere in the milieu ofJewish leaders and public figures when Fayșal died. Emergency committees, meetings and gatherings were convened and strategies were elaborated:

Beside grief, Jews are anxious about their future, too. One could see that as soon as the news spread, Jews met in groups in order to speak about tomorrow, as [Fayșal's] heir is not known to be well-disposed towards Jews, as was his father. The young sovereign has always been the hope of extremist nationalists of the country. ${ }^{19}$

16 Ibid

17 Iṣhāq Bar Moshe (1927-2003) was born in Baghdad in a religious family. He studied at the Faculty of Law and left Iraq in 1950. His autobiographical trilogy (Al-Khürüj min Al-'Trāq (1975) Bayt Fı̀ Baghdād (1983) Ayyām Al-'Trāq (1988)) is an extremely rich account of the every day life of a Jewish family in the old Baghdad. He died in Israel in 2003.

18 Ișhāā Bar Moshe, Bayt fì Baghdād, Jerusalem, Manshūrāt Rābițat al-Jāmi iiyyīn al-Yahūd al-Nāzihīn min al-Irāq, 1983, 227-229.

19 "Robert Méfano, Baghdad, 13 September 1933", AIU Archives. "A la douleur de la perte du roi s' ajoutait l' anxiété de l' avenir. On pouvait voir, aussitôt la nouvelle répandue, des Juifs 
Fayșal was much popular and appreciated among Jews than was his son Ghāzì. But the question that rises at this point is the following: is the Jews' expression of grief to the death of their monarchs related to the degree of sympathy they felt for them? The following comparison between the two sets of ceremonies will bring elements of answer to this question through an analysis of the performances and their messages.

\section{Fayṣal's Death (1933)}

Fayșal I died of a heart attack in Bern (Interlaken) on 8 September, 1933. Before being sent back to Baghdad, his body followed a long itinerary, first from Switzerland to Brindisi in Italy. From there the body "was embarked on an Italian boat and towed alongside H.M.S. Despatc H" to Palestine, in a coffin "conveyed on a horse-drawn carriage". ${ }^{20}$ During the journey, the coffin was taken into pieces, as its dimensions were too big, for the room designed for that purpose. After the body had arrived in Haifa on 14 September, the coffin was "taken direct to Baghdad by air"21 on 15 September.

In Baghdad, the news of his death spread early in the morning of 8 September 1933. Right after the afternoon prayer, processions of people were formed and representatives of every community started to proceed through the city "beating their breasts and wailing dirges", according to the American Consul General in Baghdad, Paul Knabenshue (1883-1942). "Members of guilds carried banners proclaiming their membership in a particular trade" and "black robed women on the house tops wept, wailed and moaned".22 Another eyewitness, Gerald de Gaury, a British official and close friend of the Iraqi monarchs, gives a similar account on the general attitude of the crowd: "Long before the hour of arrival the streets were lined by inhabitants, the great majority crying without restraint." The women, according to him were also "covered in their usual

se réunir en de colloques où il était question du lendemain, l' héritier ne jouissant pas de la même réputation de bienveillance à l' égard des Juifs. Ce souverain jeune a de tout temps été l' espoir des nationalistes extrémistes du pays." [Original spelling].

"Message and letter from Captain Drummond, HMs Despatch, 14 September 1933," in Records of the Hashimite Dynasties, ed. Alan de L. Rush, Vol. 11, 779.

21 "Paraphrase telegram from High Commissioner for Palestine to Colonial Secretary, London, 11 September 1933," 777.

22 "Mr P. Knabenshue, Baghdad to Secretary of State, Washington, 19 September 1933," in Records of the Hashimite Dynasties, ed. Alan de L. Rush, Vol. 11, 793-794. 
black veils and cloaks, lined the balconies and roof-edges, where they rocked and moaned and shrieked in unison and were but little less subdued than their men."23

A mourning of seven days was declared, during which all shops closed, amusements banned, and flags were flown at half-mast. When the body arrived in Baghdad on 15 September accompanied by Fayșal's brother and officials, the body was placed on a gun-carriage, with "a large portrait of the late king, draped in black crepe, while the top of it was surmounted by about a dozen Iraqi flags on small flag staffs". The procession passed across Maude Bridge, to the Royal Court, where more than five hundreds official guests were waiting to join the procession. All eventually arrived together at the royal tomb that had been built next to the Parliament House. After the booming of ninetynine guns and prayers "the funeral of King Faisal I came to an end". ${ }^{24}$ All eyewitnesses, especially Westerners who were not used to these expressions of grief, insist on the fervor of the crowd. De Gaury writes: "When the whole people of a city or countryside are mourners, as was the case at the death of King Faisal and later at the death of King Ghazi, then the scene is to Europeans truly eccentric." 25 At times, Knabenshue is also moved by the "outpouring of deep emotion" and deeply impressed by the "uncontrollable crowd" and "thousands of excited Arabs [...] bemoaning the untimely death of their king". ${ }^{26}$

Robert Méfano, head of the AIU, sends a report to the headquarters in Paris on 13 September, in which he describes a specifically "Jewish procession" that took place on 10 September, i.e. two days after Fayșal's death was announced. It appears from the report that Méfano did not personally attend the ceremony, as he asked the Great Rabbi and President of the Jewish community Sāsūn Khaḍdūini, ${ }^{27}$ leading organizer, to give him a precise account of the procession. According to his testimony, the procession started at $3 \mathrm{pm}$, with about 1000 people gathered in the schoolyard of the Midrash school. ${ }^{28}$ All teachers wore

23 Gerald de Gaury, Three Kings in Baghdad, The Tragedy of Iraq's Monarchy, (New York: I.B. Tauris, 2008 (1961)), 91.

24 "Mr P. Knabenshue, Baghdad to Secretary of State, Washington, 19 September 1933," 793794 .

25 Gerald de Gaury, Three Kings in Baghdad, 93.

26 "Mr P. Knabenshue, Baghdad to Secretary of State, Washington, 19 September 1933," 794.

27 Born in Baghdad in 1886, Sāsūn Khaḍụūrī became Great Rabbi in 1928, and President of the Jewish community (ra'is al-tă $i f a$ ) in 1931. He occupied this position until his death in 1971 (except for a few years in the 1950s). 
black armbands and the Great Rabbi addressed two prayers; the first one to "the soul of the great king whose death has prematurely snatched him from his nation and its children", ${ }^{29}$ and the second to Ghāzī, his son, so that he finds the strength and wisdom to rule his subjects. Finally, the Great Rabbi delivered a speech that made all members of his audience cry.

At $3.30 \mathrm{pm}$, the group started to walk, headed by 2000 students, "a burning candle in hand", followed by the Great Rabbi and other rabbis. After them came notables, Jews organized by quarter, and women wearing black "tcharchafs". Soon, more than 1000 bare-chested men, "beating their chest with both hands on the rhythm of kettledrum, ${ }^{30}$ joined the procession from adjacent streets. The group was then divided into three parts, each scanning in turn an oration from the Jewish poet al-Baghdādī. ${ }^{31}$ While one group was singing, the others were beating their breasts "according to the Arab custom". According to the Great Rabbi, some 55,00o people ${ }^{32}$ were chanting:

"O, people, make your tears flow

Ghazi's father, the hard-working, is no more.

You disappeared from among us, our King,

You have left, leaving us in grief

The king of the Arabs is gone

Abandoning his cub

O dear Ghazi, our precious

In you, we put all our hopes, after him"

Members of the Jewish procession held banners with such inscriptions: "The Israelite community mourns your loss, $\mathrm{O}$ father of Ghazi"; "All our condolences go to you, O Ghazi, we will die for you"; "All our eyes cry". When they arrived at the Royal Court, speeches were delivered. And according to Méfano, nonJewish witnesses were so moved by these expressions of grief, that they "spon-

pupils studied in the school, and in 1913, about 2700. The graduates from the Midrash Talmud Torah founded the Zilkha Yeshiva in 1840. For more on the Midrash school system and curricula, see the contribution to the present volume by Sasha Goldstein-Sabbah: "Jewish Education in Baghdad: Communal space vs. public space". "Robert Méfano, Baghdad, 13 September 1933", AIU Archives.

$30 \quad$ Ibid.

31 Méfano mentions "the Jewish poet from Baghdad". He most likely refers to the ntth century Arabic poet of Jewish origin Abū al-Barakāt al-Baghdādī.

32 Local press reported 6o,ooo. 
taneously spoke" 33 publically and in good terms of the Iraqi Jews. Some moving "incidents" were reported, such as the story of a Muslim man who ran towards the Great Rabbi, in order to personally thank him in the name of the Muslims for the Jews' expression of grief. Other Muslim members of the crowd climbed up a ladder and shouted that Jews and Muslims were brothers. The procession came to an end at around $10.30 \mathrm{pm}$. When the Jews left the Palace, it was dark and all lights were turned off. Thousands of people were chanting monotonous orations and beating their chest rhythmically, while women were moaning. Old men were marching next to the children, in a gloomy atmosphere. Police officers were said to have offered the old rabbis to drive them back home.

The succession of all these performances offered an "impressive" sight, according to the report. The witness Iṣhāq Bar Moshe also expresses his astonishment, while giving a very similar account of the events:

I remember vividly King Fayșal's death. I remember that all men of our house went out in the streets to see the enormous funeral procession. One could read real grief on everyone's face [...] The day the funeral procession took place, after his body was sent back from Switzerland, is unforgettable. I heard people from inside and outside the house asking God to have mercy upon the king, and spoke well of him. All men wore a special cap that the king used to wear and that they named after him, faysaliyya. ${ }^{34}$

Méfano concludes his report by stating that the procession and participation to the national mourning was successful in terms of recognition, contrary to the Christian community whose representatives were criticized for their "lack of effusiveness". King Ghāzī is said to have been impressed by the Israelites and while the nationalist newspaper Al-'̄lam al-'arabì looked at this demonstration of grief with suspicion, other newspapers openly blamed the attitude of the nationalist newspaper, that was consequently asked to make up for its tactlessness, in a following issue. "In conclusion, according to H.E. the Great Rabbi, a great reversal took place in favor of the Jews". ${ }^{35}$

Several pieces of evidence lead to the conclusion that the prevailing message of the communitas is one of religious harmony and solidarity. First, the similarity between the processions organized by Jews only, and those organized

"Robert Méfano, Baghdad, 13 September 1933", AIU Archives. "s' improvisèrent orateurs" [Original spelling].

34 Ișhāa Bar Moshe, Bayt fì Baghdād, 227-229.

35 “Robert Méfano, Baghdad, 13 September 1933", AIU Archives. 
by non-Jewish Iraqis is striking. The Jews' expressions of grief are modeled on that of the other ceremonies. Méfano stresses that the ceremony followed the "Arab custom", and Ibrāhim al-Kabīr writes that all processions followed "the old fashioned Arab style": ${ }^{36}$ men beating their chest, women moaning and wearing black, the crying, the chanting and the scanning; everything in the Jewish ceremony echoes the other ceremonies. Second, their "spontaneity" and "effusiveness" is acknowledged by King Ghāzī himself. Third, non-Jewish Iraqis physically and orally engage in these performances of ecumenical nature. As the procession unfolds, non-Jewish mourners join: the cortege starts with 1000 people and ends with 55,000, or more. Similarly, non-Jews are said to be chanting with Jews, climbing the ladder to thank the Great Rabbi, and policemen are reported driving old and tired Jews back home. All these elements illustrate the complete-yet temporary — collapse of the ordinary social structure, and allow the anti-structure to emerge. This is characteristic of the liminal phase, when unordinary things become possible. The carnivalesque allows mourners to imitate real life in a caricature fashion — and in this case an ideal life, where interreligious harmony prevails.

The context surrounding Fayșal's death was one of transition: independence had just been achieved (1932), and all hopes were at first entertained. But the massacre of hundreds of Assyrians in the northern part of Iraq in August 1933 by the army led to a general feeling of insecurity among non-Sunni communities. In the Iraqi press, Assyrians were depicted as a threat to the Iraqi national security and unity. ${ }^{37}$ Consequently, the worst threat for Jews was being accused of ța ifiyya-sectarianism, and for not being enough engaged in interacting with other communities. In these performances and in the way they were reported by media coverage, emphasis had therefore to be placed precisely on this interaction; its spontaneity, solidarity, and intensity. And when Méfano compares the weak Christian performance to the "effusive" one organized by the Jews, when he reports the king's approval and the fact that the nationalist newspaper Al-'Álam al-'arabī has been ostracized because of its anti-Jewish position, he states that the effort was crowned with success. The community representative therefore tacitly acknowledges that the ritual has a very specific social function in a very specific political context. Following Marcel Mauss' interpretation of magic rituals, the ceremony can be said to have been truly effective. ${ }^{38}$

36 Ibrahim Al-Kabir, My Governmental Life, 86.

37 Charles Tripp, A History of Iraq, (Cambridge: Cambridge University Press, 2007), 76.

38 See for example: Henri Hubert and Marcel Mauss, "Introduction à l' analyse de quelques phénomènes religieux", Mélange d'histoire des religions, (Paris: F. Alcan, 1909), 15. 


\section{King Ghāzīs Death (1939)}

King Ghāzī died on April 3rd at 11.30 pm, following a car crash on his way from his private radio station to Qașr Al-Zuhūr (Royal Palace). According to the official report, "as he went over the conduit at high speed, the front wheels must have left the ground, so that, when he tried to bear to the left, he had no control. The car ran into a telegraph pole which cracked and fell forward, smashing his head". ${ }^{39}$ The newspapers were suppressed the morning after, even though they were printed too early for the news to be published. The news started to spread anyways, and the suppression was accordingly received with suspicion by public opinion..$^{40}$ Rumours accusing the British of being responsible for the king's death consequently spread like wildfire. Later that day, three communiqués were issued; in the first one, the king's death was announced, the second one contained a medical report in response to the rumours, and the third one announced the accession to the throne of his son Fayșal II and the appointment of Amir 'Abd Al-Ilāh as Regent. ${ }^{41}$

The king's body was immediately transported to the Royal Court, but the car was left untouched for days, in order to show evidence to the thousands of onlookers that it was an accident, and not a murder. Ibrāhīm Al-Kabīr visited the scene several days after it took place and writes:

39 Gerald de Gaury, Three Kings in Baghdad, 110.

40 "American Legation, Baghdad to Secretary of State, Washington, Despatch No. 1275, with enclosures, 12 April and further communication," in Records of the Hashimite Dynasties, ed. Alan de L. Rush, Vol. 12, 629 .

41 Despite British insistence that Prince Zayd should be regent instead of 'Abd Al-Ilāh, the proposition was overruled by both the British chargé d'affaires based in Baghdad, Mr. Houstoun-Boswall and Nūrī Al-Sa'īd, who thought that Amir Zayd's wife was "ambitious, venal [...], susceptible to German influences and in touch with all sorts of untouchable circles in the Middle East”. Right after the crash, Queen 'Aliyā' is said to have asked Dr. Sinderson, the king's personal physician, to give him a strong injection, while he was dying, insisting that he should name a Regent before he dies. She then said that he had murmured 'Abd Al-Ilāh, the Queen's brother. It was considered evidence by the council of ministers and the decision was approved by a joint session of Senate and Chamber of Deputies on 6 April. "Telegram from American Legation, Baghdad to Secretary of State, Washington, 6 April 1939," in Records of the Hashimite Dynasties, ed. Alan de L. Rush, Vol. 12, 607. "Mr Houston-Boswall, Baghdad to Foreign Office, London, 6 April 1939," in Records of the Hashimite Dynasties, ed. Alan de L. Rush, Vol. 12, 6o8-6og. Matthew Elliot, "The Death of King Ghazi: Iraqi Politics, Britain and Kuwait in 1939," Contemporary British History, 20 (3), 75 . 
His death was followed by rumors that he was the victim of a plot engineered by Nouri Al Said with British connivance. Many people were invited to visit the scene of the accident and with some colleagues I did the same and saw the badly damaged car resting against a tree a short distance from Qasr-al-Zehour. There could be no doubt about the accident, particularly when Ghazi was known to be a reckless driver and speed addict. $^{42}$

While the body was being transported to the Royal Palace, groups of people already started to follow the coffin, with "mourners, wailing, beating their breast and tearing their hair in the intensity of their grief". ${ }^{43}$ According to Gerald de Gaury: "Ghazi was mourned by the emotional people of Baghdad with great intensity. From early morning processions of people weeping and beating their breasts passed through the main streets and the wail of women gave a macabre note to an unforgettable scene." 44

On 5 April, the official funeral took place. At 8 am, the procession left the Royal Court, heading to the mausoleum in A'dhamiyya, where King Fayșal and King 'Alī were buried. They arrived there at $9 \mathrm{am}$. Prayers were recited in front of thousands of mourners, and a salute of ninety-nine guns was fired. According to Houstoun-Boswall, British chargé d' affaires based in Baghdad, the crowd was in "a fever of hysteria". Iraqis who attended the procession were crying. Some women "abandoned themselves to hysterical grief", "covering their heads and breasts with mud from the gutters". 45 The fätiha was read and the body was interred. Similarly, the journalist who reported for Iraq Times, wrote that "the police had a formidable task to perform in maintaining order owing to the general feeling of hysteria prevailing among the populace". ${ }^{46}$ The American representative Knabenshue described the event as "impressive", 47 and was surprised to see "soldiers and even policemen sobbing like children".48

\footnotetext{
42 Ibrahim Al-Kabir, My Governmental Life, 101-102.

43 "Houstoun-Boswall/Halifax, Baghdad, 11 April 1939," in Records of the Hashimite Dynasties, ed. Alan de L. Rush, Vol. 12, 617 .

44 Gerald de Gaury, Three Kings in Baghdad, 111.

45 "Houstoun-Boswall/Halifax, Baghdad, 11 April 1939," 618.

46 Iraq Times, 6 April, 1939, in Records of the Hashimite Dynasties, ed. Alan de L. Rush, Vol. 12, 639 .

47 "Telegram from American Legation, Baghdad to Secretary of State, Washington, 6 April $1939, " 607$.

48 "Houstoun-Boswall/Halifax, Baghdad, 11 April 1939," 617.
} 
In a similar way to Fayșal's funeral in 1933, members of the Jewish community throughout the country publicly expressed their sorrow, by organizing ceremonies in honor of their "beloved king". ${ }^{49}$ Robert Méfano, now director of the Reemah Kadoorie Jewish school for girls (AIU) in Basra, sent a fully detailed description of the reaction of the school authorities to Paris. According to the report, the flag was immediately flown at half-mast. Within an hour of the announcement of the king's death, he asserted, all the pupils gathered in the schoolyard, in tears. Teachers ran to the local fabric store-which opened especially for this occasion - and sewed banners and armbands for the school's scouts. All girls wore their black overalls without the usual white collar. Rapidly, a procession led by two teachers dressed in black "from top to toe" started to proceed; one held a portrait of the king, the other an Iraqi flag. Two tall students held a black banner with the following inscription: "The mourning Alliance Israélite schools offer their condolences to Faiçal II, to the Queen Mother and to the Hashimi family." $55^{\circ}$ girls were followed by boy scouts with black armbands holding a banner with the inscription: "Our beloved King is dead, long live the King". When the group left the school, it was joined by members of the AIU Alumni Association and the Jewish Youth Association. The fanfare, covered by a black veil played a funeral march, while two groups of pupils sang, in turn. The first group sang: "Our beloved King is dead, we mourn for him from the bottom of our heart"; and the second group responded: "we mourn for him". Women moaned, and men beat their chests rhythmically, following the "Arab custom". Some people covered their faces with mud. Progressively, various members of the city's population also joined the procession including Jewish notables, and a dense crowd of non-Jews. The mourning crowd eventually reached the Governorate building, where a State representative officially thanked them for their condolences and greeted their spontaneity. Méfano insists on how emotional the scene was: "I could not describe to you how emotional the procession was. Those who saw them along the way could not hold back their tears." 50

A memorial service organized by the AIU teachers took place at the school again, a few weeks later (23 April). The local authorities, the President of the Jewish community in Basra Sāsūn 'Ābid, ${ }^{51}$ and numerous Jewish nota-

49 Al-Thughūr, Basra, April 1939 (exact date unknown), AIU Archives.

50 "Robert Méfano, Basra, to President of AIU Paris, 14 April 1939", AIU Archives. "Nous ne saurons vous décrire combien le cortège était émouvaut. Le long du parcours ceux qui le voyaient passer ne pouvaient contenir leurs larmes." [Original spelling].

51 Born in Baghdad in 1898, Sāsūn 'Ābid settled in Basra after the First World War. Active 
bles attended the ceremony. In his speech, the President of the community repeatedly declared the community's loyalty to its "Arab nation" (li-ummatina al-'arabiyya) and towards its "admired king" (al-malīk al-mu'azzam). And he concluded with these three words: "God. The King. The Nation (al-watan)."52 The service was followed by a speech delivered by a young pupil. In the words of the school's director, "every time she addressed the portrait of the late king, her heartrending voice would make all the people cry, without exception".53 The ceremony ended with a funeral lament composed by one of the teacher, and sung by a group of twenty girls and twenty boy scouts. The ceremony is said to have "moved the Muslim element". Al-Thughür, a newspaper known to be unsympathetic to the Jews, printed Sāsūn 'Ābid's speech word by word, and commented favorably on the ceremony.

The rules of predictability impose certain ritual similarities with Fayșal's funeral, in terms of organization, media coverage and efficacy. The crying, the moaning, the beating, the black covering, and the "Arab custom" in general are said to have "moved" the Muslims, as well as the State representative and the national press, who acknowledge their efforts and sympathy. But the dissimilarities and malleability of the ceremony need to be explored, too. Two aspects in particular emerge from the comparison with the 1933 mourning ceremonies; the feeling of tragedy and the importance of pan-Arab nationalism.

First, the ceremony is organized "within an hour of the announcement", while it took the Baghdad school community two days to organize a Jewish procession when Fayṣal died in 1933. The report insists that the local fabric store was opened especially for the occasion, that some people covered parts of their body with mud, and that women wore black "from top to toe", which was not the case in 1933. The carnivalesque, here, serves to imitate real life, by highlighting its dark side - and not anymore its ideal one. For example, the girls wore their usual black overall during the funerary ceremony, but they just removed the white collar, so as to be totally dressed in black. And in Méfano's single report, the word "black" is used five times. Generally speaking, the Jewish

in politics there, he was appointed President of the Jewish community in Basra ( $r a^{\prime} \bar{s}$ al$t \underline{a}$ i $i f a$ ). After the Second World War, he moved back to Baghdad and to Canada after the 1958 Revolution, where he died in 1990.

$5^{2} \quad$ Al-Thughūr, Basra, April 1939 (exact date unknown), AIU Archives.

53 "Robert Méfano, Basra, 27 April 1939", AIU Archives. "Une jeune fille de l'école de Reemah Kaddourie a prononcé un discours. Chaque fois qu'elle s' adressait au portrait du defunt Roi, avec des accents déchirants, tous sans exception versait des larmes." [Original spelling]. 
response to Ghāzìs death is thus described as more committed and expressive of the grief provoked by the loss of their sovereign. His death is perceived as a tragedy and not—as was the case with Fayșal in 1933 — as a spontaneous and almost miraculous moment of epiphany between members of "every creed". 54 The feeling of emergency is very salient in 1939 and the ceremonies organized by Jews in 1939 took a much more dramatic turn than in 1933.

Matthew Elliot concludes that Ghāzì was killed as "a result of a conspiracy between Nuri and Abdulillah (and possible Aliya too) encouraged by appropriate hints from the British". 55 To clarify the question whether the British were responsible or not for Ghāzì's death—it goes without saying — is far beyond the scope of this paper. Rather, it aims at assessing the impact of this context of conspiracy speculations, on the way the funerary ritual performed by the Jews. At the time of Ghāzì's death, Iraq was experiencing a period of unprecedented tension. The situation was characterized by a strong polarization, leading to the formation of two factions: the pro-Nürì Al-Saîd on the one hand, who supported the British, and the pro-Ghāzī on the other hand, who advocated a rapprochement with Germany. His car crash and the supposed British involvement in it contributed to increase the polarization and to intensify the animosity. The first clashes started very quickly after the announcement of the monarch's death. Typewritten pamphlets were distributed and speeches were delivered, in which the British were accused of murder. Houstoun-Boswall had to be personally escorted by the Criminal Investigation Department, and despite his numerous requests "to restore calm and to suppress the false rumours", ${ }^{6}$ the tension was at its peak. The car of another British official was attacked in Ramadi. Shops were closed and "streets patrolled by troops and armored cars".57 After the British Consul in Mosul tried to quieten the people by addressing them from his balcony, members of a mob forced their way inside the house, and one of them "hacked him down" 58 with a pickaxe. British reports insist that the German propaganda directed by the ambassador Fritz Grobba was indirectly responsible for the death of the consul in Mosul and for rumours accusing the British of having killed Ghāzī. ${ }^{59}$ Some members of a secret society formed

54 "Mr P. Knabenshue, Baghdad to Secretary of State, Washington, 19 September 1933," 793.

55 Matthew Elliot, "The Death of King Ghazi: Iraqi Politics, Britain and Kuwait in 1939," 76.

56 "Houstoun-Boswall/Halifax, Baghdad, 11 April 1939," 618.

57 "Telegram from American Legation, Baghdad to Secretary of State, Washington, 6 April 1939," 6o7.

$5^{8}$ Matthew Elliot, "The Death of King Ghazi: Iraqi Politics, Britain and Kuwait in 1939," 68.

59 "Telegram from American Legation, Baghdad to Secretary of State, Washington, 18 April 1939," in Records of the Hashimite Dynasties, ed. Alan de L. Rush, Vol. 12, 665. 
by students and civilians were sentenced from three to fifteen years' imprisonment with a fine of ten dinars by court-martial for inciting to rebel against the State, and some were sentenced to fifteen lashes. ${ }^{60}$ But the word had already spread: the rumour was said to have found an audience in Beirut and Damascus, broadcasted on German radio and reported in the Italian press. ${ }^{61}$ The consequences of these accusations directly affected the Jews, who were often perceived as allies of the British. In Kirkuk for example, anti-Jewish demonstrations took place at the same time as those against the British. ${ }^{62}$ So, were the rumours to intensify and were the Jewish leaders not to express full loyalty to their king, their sincere sadness and total dissociation from British supposed intrigues against the monarchy, unwanted consequences could be felt.

Second, Ghāzī had led a harsh pan-Arab campaign for legitimizing the occupation of Kuwait, mainly through his own radio broadcast. ${ }^{63}$ And unlike his father who prioritized the Iraqi nature of the national identity at a time when the modern State of Iraq had to be built from scratch in accordance with the British, Ghāzī had turned his back on the colonial power and promoted panArabism as a discursive tool against it. Pan-Arab terminology and references were accordingly unprecedentedly strong in the public space. In the Palestinian poet Akram Zu'aytar's speech delivered on a commemorative ceremony that took place on the final day of mourning (14 May) in Baghdad, references to Arabism were very strong. The word "Arab" was used seventeen times. ${ }^{64}$ Mirroring this trend, the influence of the pan-Arab terminological repertoire is also prominent in the speech delivered by the President of the Jewish community in Basra. The term "Arab" was used six times-four times accompanied with the word "nation" (al-umma al-'arabiyya ), ${ }^{65}$ typical of the pan-Arab repertoire.

Here, the language used in the public space unveils a socio-political context heavily charged in favour of a pan-Arab and pro-German community of

$60 \quad$ "Extracts from the Iraq Times, 27 April 1939," in Records of the Hashimite Dynasties, ed. Alan de L. Rush, Vol. 12, 667-669.

61 "British Embassy, Rome to Lord Halifax, Fo, London, 5 April 1939," in Records of the Hashimite Dynasties, ed. Alan de L. Rush, Vol. 12, 656-657.

62 "American Legation, Baghdad to Secretary of State, Washington, Despatch No. 1275, with enclosures, 12 April and further communication," 630.

63 Matthew Elliot, "The Death of King Ghazi: Iraqi Politics, Britain and Kuwait in 1939," 65-70.

64 "Al Bilad newspaper, 18 May 1939. Enclosure to report from Mr Houston-Boswall, Baghdad to Lord Halifax, London," in Records of the Hashimite Dynasties, ed. Alan de L. Rush, Vol. 12, 686-689.

65 Al-Thughür, Basra, April 1939 (exact date unknown), AIU Archives. 
discourse, that Jews needed to adopt fully and at all costs if they wanted to crown their efforts with success, as they did when Fayșal died. This time, the message of religious pluralism and desire to coexist at peace with other communities was not enough for the Jews. Contrary to Fayșal's death where emphasis was given to their will to interact with other communities, the attention was much more focused on loyalty towards the State, the king, and the Arab nation.

\section{Conclusion}

In these times of mourning, the public space becomes a political arena for performance, where less influent elements of the society temporarily become visible by using the power of communitas. This paper has shown that in September 1933 as well as in April 1939, Iraqi Jews seized the opportunity to take over the public space, and send a performed message. The message varied according to the context: religious pluralism was the message at Fayșal's death when struggle against sectarianism and promotion of Iraqi homogeneity prevailed, while loyalty to the Arab nation and king dominated the discourse in the 1939 ceremony, after Ghāzīs intense pan-Arab campaign in all arenas of the public space. From this difference, we can conclude that even though the Jewish mourners may have - or may have not-been affected by the loss of the monarchical figure, the way they acted in the public space does not indicate the degree of intensity of their emotions during the ceremonies. Rather, it provides with tools to understand the values or necessities of the State at the time of their taking place.

During a more recent funeral of a Hashemite monarch, that of King Husayn of Jordan who died on 7 February 1999 in Amman, the communitas once more proved its function. The reporter insists that Husayn's death gathered presidencies from all around the world, "to pay their last respects" to the king. Bill Clinton, George Bush, Jimmy Carter and Gerald Ford, Hafez Al-Assad, Boris Yeltsin, Benjamin Netanyahou, Hosni Mubarak and many others, were present. Despite the obvious similarities with the other Hashemite ceremonies examined in this paper, the message of the communitas is very new and much more international. King Husayn of Jordan's funeral is said to have greatly contributed to the advancement of the peace process in the Middle East. The journalist presents a man who managed to "balance the pressures of the Arab world" and he emotionally announces that the "secretary general of the Damascus-based Democratic Front for the Liberation of Palestine was able to shake the hand of President of Israel Ezer Weizman. The first time anything like 
that has happened."66 In other words, the message is one of necessity for peace in the Middle East, between Israel and the Arab States.

\section{Bibliography}

\section{Primary Sources}

Records of the Hashimite Dynasties, A Twentieth Century Documentary History, ed. Alan de L. Rush (Slough: Archive Editions, 1995), volumes 4, 11 \& 12, covering the death of King Ḥusayn (1931), King Fayșal (1933) and King Ghāzī (1939)—National Archives, Washington DC and National Archives, London.

Archives of the Alliance Israélite Universelle, Paris

Ibrāhīm al-Kabīr, My Governmental Life, or Story of a Dream, 1964 (unpublished manuscript), Babylonian Jewry Heritage Center, Or Yehuda.

Bar Moshe, Ișhāq. Bayt fí Baghdād. Jerusalem: Manshūrāt Rābiṭat al-Jāmi iyyīn al-Yahūd al-Nāziḥīn min al-'Irāq, 1983.

De Gaury, Gerald. Three Kings in Baghdad, The Tragedy of Iraq's Monarchy. New York: I.B. Tauris, 2008.

\section{Secondary Sources}

Bakhtin, Mikhail Mikhaĭlovich. Rabelais and His World. Bloomington: Indiana University Press, 1984.

Bashkin, Orit. New Babylonians: A History of Jews in Modern Iraq. Stanford: Stanford University Press, 2012.

Bloch, Marc. The Historian's Craft. trans. New York: Knopf, 2004, 27-29.

Cannadine, David. "The Context, Performance and Meaning of Ritual: The British Monarchy and the 'Invention of Tradition', c. 1820-1977." in Eric Hobsbawm and Terence Ranger (eds.). The Invention of Tradition. Cambridge: Cambridge University Press, 1983, 101-164.

Cole, Juan. "Iraq in 1939: British Alliance or Nationalist Neutrality toward the Axis?" Britain and the World 5, no. 2 (2012): 204-222.

Durkheim, Emile. The Elementary Forms of the Religious Life. trans. London: Courier Dover Publications, 2012.

Elliot, Matthew. "The Death of King Ghazi: Iraqi Politics, Britain and Kuwait in 1939." Contemporary British History, 20 (3), 63-81.

Enders, Armelle, "Le héros national, problème d'histoire contemporaine," in Cather-

66 "King Hussein Funeral Service, C-SPAN, Washington, 8 February 1999," http://www.c-span .org/video/?120220-1/king-hussein-funeral-service (Consulted on 31 March 2014). 
ine Mayeur-Jaouen (dir.), Saints et héros du Moyen-Orient contemporain, Paris: G.P. Maisonneuve et Larose, 2002, 37-46.

Goffman, Erving, Forms of Talk, Philadelphia: University of Pennsylvania Press, 1981.

Hubert, Henri. and Mauss, Marcel. "Introduction à l' analyse de quelques phénomènes religieux," Mélange d'histoire des religions Paris: F. Alcan, 1909.

Ireland, Philip Willard. Iraq: A Study in Political Development. London: J. Cape, 1937.

Kristeva, Julia. Sēmeiōtikē: recherches pour une sémanalyse. Paris: Seuil, 1978, 146.

Tripp, Charles. A History of Iraq. Cambridge: Cambridge University Press, 2007.

Turner, Victor. The Anthropology of Performance. New York: PAJ Publications, 1988.

- The Ritual Process: Structure and Anti-Structure. London: Routledge and Kegan Paul, 1969.

Van Gennep, Arnold. Les rites de passage: étude systématique des rites. Paris: E. Nourry, 1909.

Wien, Peter. "The Long and Intricate Funeral of Yasin al-Hashimi: Pan-Arabism, Civil Religion, and Popular Nationalism in Damascus, 1937." International Journal of Middle East Studies 34, no. 2 (2011): 271-292. 